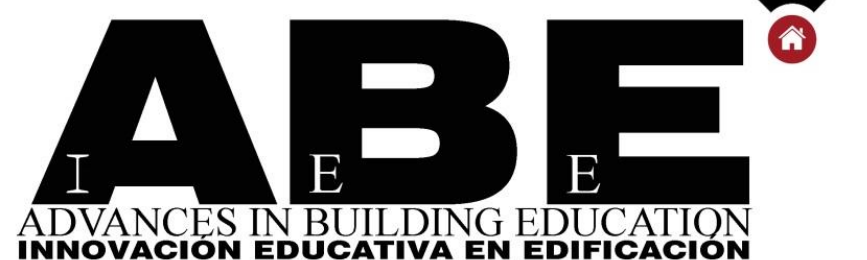

\title{
Education for sustainable development in building higher studies
}

\author{
Cristina Marieta ${ }^{1}$, Iñigo León ${ }^{2}$, José Antonio Millán-García ${ }^{3}$, Alexander Martín-Garin $^{3}$ \\ ${ }^{1}$ Department of Chemical Engineering, Faculty of Engineering of Gipuzkoa, University of the Basque Country UPV/EHU, \\ Plaza Europa 1, 20018 Donostia-San Sebastián, Spain; cristina.marieta@ehu.eus \\ ${ }^{2}$ Department of Architecture, Faculty of Engineering of Gipuzkoa, University of the Basque Country UPV/EHU, Plaza Europa \\ 1, 20018 Donostia-San Sebastián, Spain; inigo.leon@ehu.eus \\ ${ }^{3}$ ENEDI Research Group, Department of Thermal Engineering, Faculty of Engineering of Gipuzkoa, University of the Basque \\ Country UPVIEHU, Plaza Europa 1, 20018 Donostia-San Sebastián, Spain; j.millan@ehu.eus, alexander.martin@ehu.eus
}

\section{HIGHLIGHTS}

- More than a change in teaching or curriculum is necessary: sustainability indicates a change of cultural paradigm

- University is called to interpret and transform reality creatively facing the social, economic and environmental challengers.

- Education for Sustainable Development, ESD, prepares learners to understand and respond to the changing world and drives sustainable development

- Problem-Based Learning, PBL, and Bachelor's Degree Dissertations within the framework of a research project on sustainability in urban planning and within the framework of a research project on the recovery of cement-based waste. 


\title{
ABSTRACT
}

\begin{abstract}
UNESCO highlights the crucial role of higher education in achieving each of the 17 SDGs (Sustainable Development Goals). Thus, students should acquire the knowledge and skills needed to promote sustainable development. In this context, the University of the Basque Country (UPV/EHU) has developed the Campus Bizia Lab programme as an initiative derived from the Project Erasmus University Educators for Sustainable Development. The aim of the initiative has been to promote a collaborative process between academic staff, service and administrative staff and students, creating a transdisciplinary community to respond to sustainability challenges within the university. In the framework of the programme, pedagogical approaches for sustainable development have been developed for the Grades of Technical Architecture and Civil Engineering at the University of the Basque Country, UPV/EHU. The paper presents the methodologies developed and analyses the effect on learning process.
\end{abstract}

Keywords: Learning; Innovation teaching; Architecture; Construction

\section{INTRODUCTION}

Education for Sustainable Development (ESD) was endorsed by UNESCO's 37th General Conference in November 2013 and was launched at the UNESCO World Conference on ESD in November 2014 [1]. The common perception was that more than a change in teaching or curriculum was necessary; sustainability indicated a change of cultural paradigm. This new worldview entailed a shift of emphasis from relationships based on fragmentation, control and manipulation towards those based on participation, mutual respect and collaboration [2]. Being University a subsystem of society, oriented by its needs, values and norms, a slow and laborious process of change was foreseen. Besides, a virus that suddenly appeared, submitted us to a total revision and University was called irretrievably to interpret and transform reality creatively facing the social, economic and environmental challengers. Globalization is called to serve and globalize all its benefits, both techno-economic and sociopolitical, as well as cultural. In this pandemic, the raison d'être of professions and jobs has become evident, they have been valued for what they do for others, for the integrity of their ethics, for knowing how to put the human person at the focus of doing and on the horizon of commitment, beyond profit, security and success. Nothing further from success and individualistic careerism, the professions have been valued for what they do for the common good. Thus, more than ever, competences proposed by ESD are needed. It is time to change teaching methods, it is the most propitious moment to make disappear stereotypical and routine study, without connection with the community, human being and nature. ESD prepares learners to understand and respond to the changing world and drives sustainable development [3]. It produces learning outcomes that include core competences, which can be summarized in twelve competences: systems thinking, interdisciplinary work, anticipatory thinking, justice, responsibility and ethics, critical thinking and analysis, interpersonal relations and collaboration, empathy and change of perspective, communication and use of media, strategic action, personal involvement, assessment and evaluation, and tolerance for ambiguity and uncertainty [4]. Thus, to develop these new competences, new pedagogical approaches have been incorporated, such as brainstorming, peer assessment, problembased learning, collaborative learning, online

Advances in Building Education / Innovación Educativa en Edificación | ISSN: 2530-7940 |

http://polired.upm.es/index.php/abe

| Cod. 2102 | Mayo - Agosto 2021 | Vol. 5 № 2 | pp. 23/31 | 
discussion forums, games and systems simulations, among others [5-8].

The UPV/EHU has developed the Campus Bizia Lab programme as an initiative derived from the Project Erasmus University Educators for Sustainable Development (2013-2016). The aim of the initiative is to promote a collaborative process between academic staff, service and administrative staff and students, creating a transdisciplinary community, to respond to sustainability challenges within the university. It is an initiative driven by the Sustainability Directorate and the Educational Advisory Service, both belonging to the Vice-Chancellor's Office for Innovation, Social Commitment and Social Action of the UPV/EHU. Bachelor 's Degree Dissertations (TFG) and Master's Degree Dissertations (TFM) from Faculties (Engineering, Education, Science, Pharmacy, Economics and business) are developed within the framework of the program. The challenges addressed in the dissertations are designed and based on needs analysis in the Campuses; thus, they not only provide a return in terms of participants (students, faculty and staff) learning, but also contribute to a more sustainable management of the university itself.

On the other hand, the duty of an academic teacher is to provide students with the capacity to associate the parts with the whole, and to go even further, establishing relationships with external elements, thus transferring ideas and generalising principles, and as mentioned above, currently, under the prism of sustainability. Thus, some teachers of the degree of Technical Architecture have developed new teaching approaches, some of them within the framework of the aforementioned BiziaLab programme. In this paper, three pedagogical approaches are presented: A Problem-Based Learning (PBL), TFG within the framework of a research project on sustainability in urban planning and TFG within the framework of a research project on the recovery of cementbased waste.

\section{METHODOLOGY}

\subsection{PBL, Problem-based learning}

Recent research studies on university teaching indicate that the essential factor to foster academic success is students' engagement in their education and training [9], understanding by engagement, the amount of physical and psychological energy that students invest in academic experience [10]. Engagement leads to the development of an activity, in the case of the university, a mental activity, which must lead directly to in-depth learning, that is, to level IV, relational, and level $\mathrm{V}$, extended abstract, according to the SOLO taxonomy (Structure of the Observed Learning Outcome) proposed by Biggs and Collis [11].

Universities of international standing have developed teaching-learning methodologies where students play a leading role in their education process, the so-called active teaching methodologies. PBL is one of the most highly developed in the university environment. In PBL, students work independently to explore a problem proposed by the professor. With this methodology, the students themselves, during the work they carry out to solve the problem, encounter the curricular objectives. The professor acts as a mere facilitator of the task rather than a source of knowledge of the discipline. The basic difference compared with traditional theoretical problems is that the ultimate objective in PBL is not to solve the problem, but to discuss how to solve the problem, which leads to the student's learning experience [12-14].

\section{Advances in Building Education / Innovación Educativa en Edificación | ISSN: 2530-7940 |} http://polired.upm.es/index.php/abe 
With PBL students develop thinking, learning and working skills, and it also enables them to better retain information, as well as integrate a working and knowledge model $[15,16]$. Moreover, with this pedagogical proposal, students acquire other transversal competencies, in addition to the typical ones of the degree: Learning independently; Applying new knowledge to solve different problems that are similar to the ones that will emerge in the different facets of their work; Working as a team under supervision; Identifying their objectives, in this case, learning objectives; Efficiently managing their time, benefiting, in this process, from their colleagues' collaboration.

Any PBL approach must have four basic ingredients: Use of a problem as a starting point to acquire new knowledge; Students' management of their own learning; Group work; Professor acting as a facilitator. And the following basic actions must be carried out to plan the PBL: Select the pedagogical objectives that, framed within the competencies established in the area, students should achieve with the activity; Propose the situation-problem that students will have to work on, which must be: relevant for the students' professional practice, complicated, but not impossible, so that it represents a challenge for students and extensive so that students can ask questions and address the problem taking into account the big picture, Guide the rules of group work and activities conducive to solving the problem; Perfectly establish the activity times; Organise tutorials where students can consult doubts, uncertainties, achievements, etc. The PBL approach was designed for a subject, which belong to module Chemistry, and Geology, Fundamentals of Materials. The subject is divided into several thematic units and the PBL was designed for the thematic unit called Material Properties and Testing. In the PBL, to work on ESD competences, not only problems associated with the subject, but also climate change, was considered. Thus, the scenario of the PBL situation-problem is in the Peine del Viento, in an important sculptural complex for the city of San Sebastián (Fig. 1). This collection of sculptures has been selected as the scenario for the problem because it is a spot that is characteristic of the city. In its objective to produce a merger between the natural and the artificial, the author used two basic construction materials: natural rock and steel, which allows us to use it as an optimum scenario to study the physical and mechanical properties of construction materials. On the other hand, the increasingly frequent storms on the coast of the Bay of Biscay, which are causing considerable damage, have led us to pose a PBL problem that can adapt perfectly to reality. In http://hdl.handle.net/10810/17756 the complete description of the resource can be found.
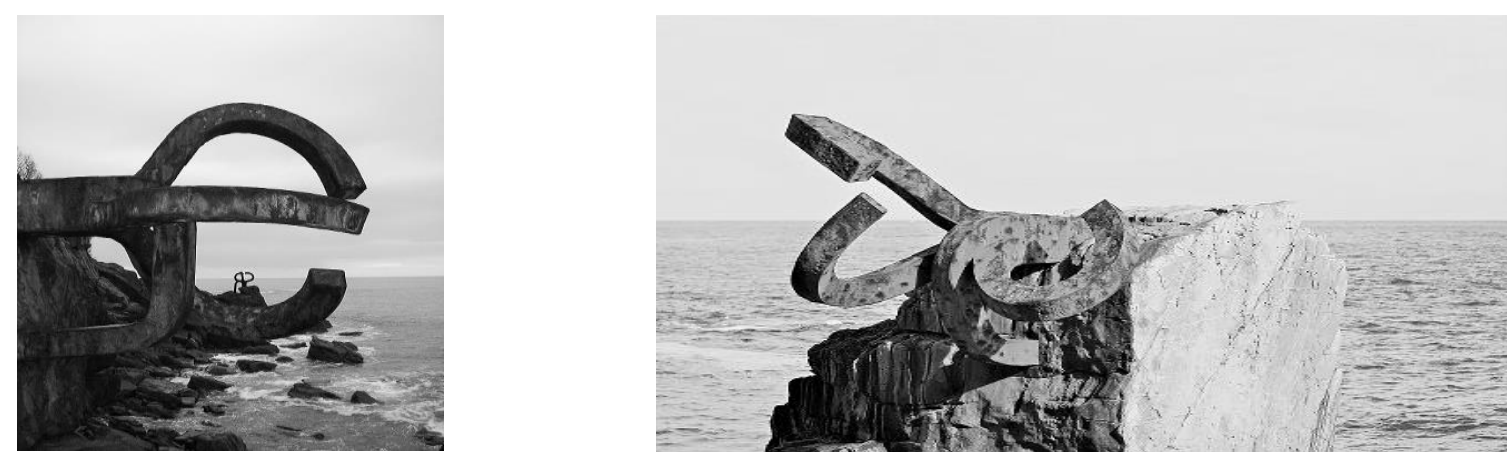

Fig. 1: Images of the three metal pieces that comprise the Peine del Viento. 


\subsection{LCA: NEST, Neighbourhood Evaluation for Sustainable Territories}

NEST was developed through a PhD thesis [17] focused on the environmental assessment of eco-neighbourhoods [18]. It is a plugin for Trimble SketchUp. Analysis is performed on the $3 \mathrm{D}$ master plan of the neighbourhood, and it performs the assessment of a set of indicators that was developed through a scientific approach to operational urban planning objectives. NEST presents a graphical and ergonomic interface, very useful for promoting analysis and action, confronting theory with reality. Thus, it is a tool that aims at assessing environmental impacts of neighbourhood scale projects, based on life cycle assessment (LCA) methodology. Besides, it allows establishing more sustainable future scenarios.

\subsection{Research}

Lozano et al analysed the relationship between ESD competences and teaching methodologies and concluded that most of the methodologies should be based on constructivism [4]. In this context, the student constructs its knowledge [19]. The most effective way to construct knowledge is by researching. Therefore, TFG students are once again involved in a research project within the framework of the Bizia Lab programme. The aim of the project is to develop a recycle methodology for the waste generated in the laboratory practices of the Building

Materials course. This debris accumulates in laboratories, just as it happens in our environment with Construction and Demolition (C\&D) materials. The methodology used in the development of the TFG is the scientific process: bibliographic review, testing, interpretation of results and conclusions. The tests carried out are, firstly, the physical-chemical characterization of the generated materials, spectroscopy, and thermographic analysis, and then, mechanical tests of bending and compression. Finally, according to the results obtained, a methodology for C\&D recycling is proposed. The methodology will be shared in conferences and journals and will be included in the programs of building higher studies.In the framework of the Bizia Lab programme a research project was developed. The aims of the project were the environmental evaluation of the four campuses of the UPV/EHU and the proposal of more sustainable refurbishment scenarios for carrying out in the next few years. To develop the research, the NEST tool was used and four TFGs were developed.

\section{RESULTS}

\subsection{PBL Problem based learning.}

The PBL was designed during the 2012-2013 academic year and was implemented in the classroom for the first time during the 2013-14 course. It has been evaluated with the text results and the degree of motivation of the students. The instrument used to measure students' motivation, has approximated the Problem Solving Inventory test, PSI [20]. The test has 20 items and, in each item, (statement) students have to evaluate their own perception following 5-point Likert-type scale (1=strongly disagree, $5=$ strongly agree). It is filled out by students at the end of term. For the statistical analysis Statgraphics Centurion 18 is used. Firstly, the mean and standard deviation (SD) for PSI test is calculated. Then, the results (on a scale of 1 to 10) of the partial examinations of physical properties (PP) and mechanical properties (MP) before and after PBL method are compared, a ttest with a significance level of 0,05 is run. Finally, the correlation between PSI scores and the results of the partial examinations is analysed. The mean and SD for PSI test are 3,3 and 1,342, respectively. In view of this result, it can be

Advances in Building Education / Innovación Educativa en Edificación | ISSN: 2530-7940 | 
concluded that the application of the PBL stimulate students' motivation to learn about materials for construction. Table 1 shows mean and SD in individual marks of the partial examinations of physical properties and mechanical properties before and after PBL.

\begin{tabular}{c|c|c}
\multicolumn{3}{c}{ Table 1: Mean and SD individual marks. } \\
\hline \hline & Mean (SD) before PBL & Mean (SD) after PBL \\
\hline PP & $5,5(2,104)$ & $6,6(2,135)$ \\
\hline MP & $4,6(1,989)$ & $6,6(2,070)$ \\
\hline
\end{tabular}

For PP a statistically significant difference is not found when comparing marks means, $t=-$ 1,52901, $p=0,134543$. However, for MP a statistically significant difference is found, $t=-$ $3,21313, p=0,00267595$. Thus, although some improvement is observed in PP, it can be only concluded that the PBL supposes a significant improvement to students in MP. Finally, regarding the correlation between PSI scores and the results of the partial examinations, Table 2 shows the Pearson correlation coefficient and the significance level (SL) for each variable correlation.

Table 2: Pearson correlation coefficient between PSI and individual marks.

\begin{tabular}{c|c}
\hline \hline Partial examinations & Pearson correlation coefficient (SL) \\
\hline PP & $0,521(0,018)$ \\
\hline MP & $0,662(0,0015)$ \\
\hline \hline
\end{tabular}

For a significance level of 0,005 significance correlation is observed in both cases, PP and MP. Pearson correlation coefficient values smaller than one represent positive correlation; thus, it can be concluded that the higher motivation the student has, the better mark he/she obtains.

\subsection{NEST, Neighbourhood Evaluation for Sustainable Territories.}

The results obtained in the development of the TFGs were presented in two congresses: in 80 Congreso Europeo sobre Eficiencia Energética y Sostenibilidad en Arquitectura y Urbanismo + 1er Congreso Internacional de Construcción Avanzada (Donostia-San Sebastián 3-5 July 2017) and Universidad y Desarrollo Sostenible. Experiencias de aprendizaje que comprometen el futuro. Conferencia internacional RED-U 2017 (Bilbao 13, 14 November 2017), one of the students gave a 20 minutes oral presentation of the work (Fig. 2 shows the graphic results). Besides, the students obtained the marks of excellent in their final dissertations.

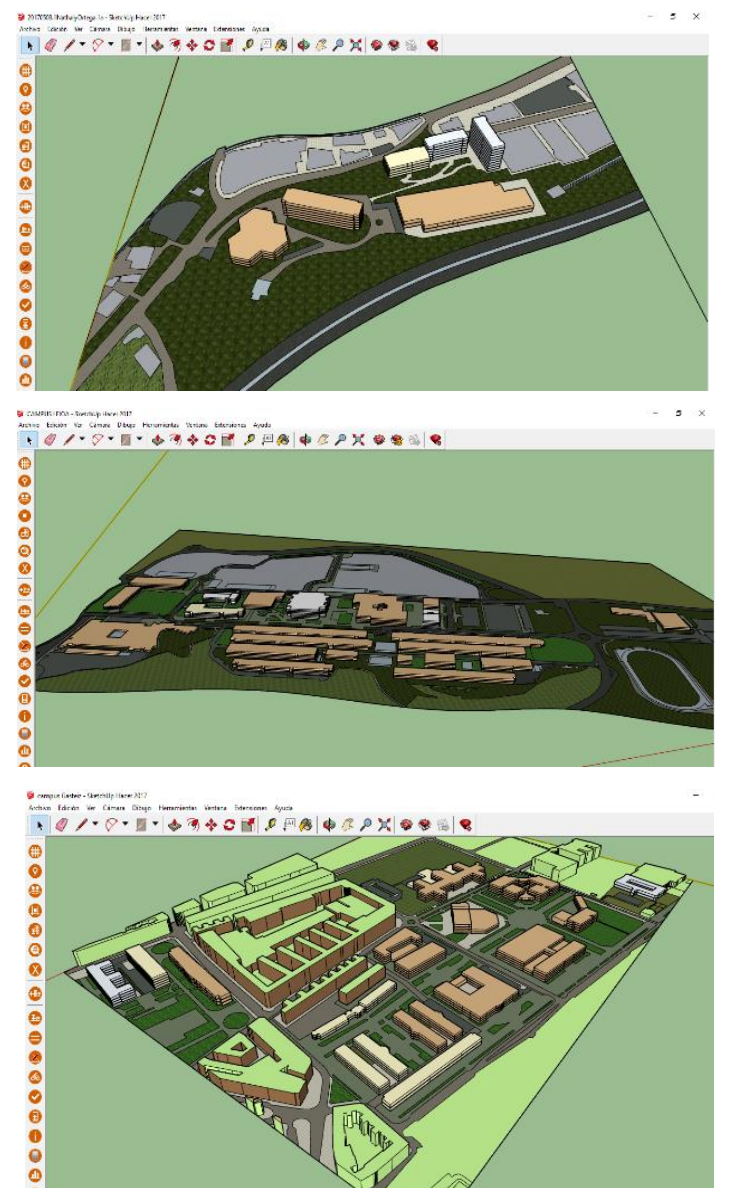




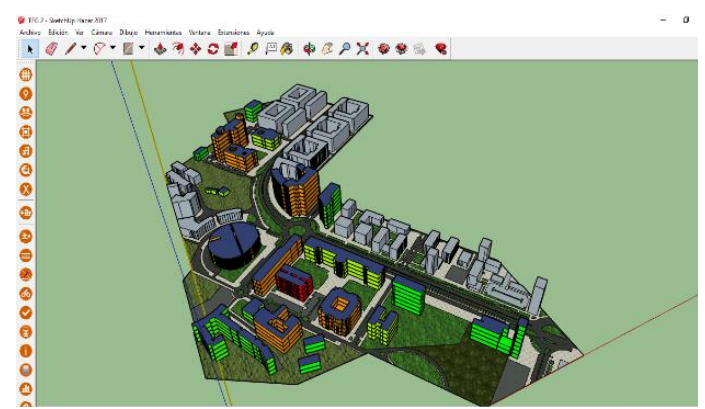

Fig. 2: Screenshots of the four campuses, Eibar, Leioa-Bilbao, San Sebastián and Gasteiz made with

\subsection{RESEARCH}

This research work is under development. The residues of cement and lime mortar test specimen have been crushed and the aggregate obtained has been classified. Thus, it can be concluded that until now the most important result has been that the laboratory residues have been recycled.

\section{CONCLUSIONS}

The Spanish humanist philosopher Ortega y Gasset already said: The principle of education depends much more on the public air in which it fully floats than on the pedagogical air artificially produced within its walls [21]. Today more than ever this statement is of fundamental interest. Thus, University has the responsibility of constructing new knowledge to face the current challenges human being, being one of the most important to deal with Climate Change and Global Warming. In the EIG (UPV/EHU) in the degrees associated with construction, through a $\mathrm{PBL}$ the students face the consequences of Climate Change. Then, using a tool based on LCA, they can propose more sustainable scenarios in urban planning. Finally, involving them in research carried out at the university, they made aware of the importance of Circular Economy. Besides, during the process, they acquire ESD competences: systems thinking, interdisciplinary work, anticipatory thinking, responsibility, critical thinking and analysis, interpersonal relations and collaboration, communication and use of media, strategic action, personal involvement, assessment and evaluation, and tolerance for ambiguity and uncertainty

\section{AKNOWLEDGEMENTS}

The authors wish to thank the ERAGIN teacher training programme in active teaching methodologies of the UPV/EHU for the help provided in carrying out the PBL, especially Estibaliz Sáez de Cámara for her help.

The authors acknowledge the UPV/EHU (Vicerrectorado de Innovación, Compromiso social y Acción cultural) for the financial support for the development of the research projects: Planificación urbana sostenible del campus de Gipuzkoa a partir del análisis de ciclo de vida and Valorización de residuos de laboratorio.

\section{REFERENCES}

[1] UNESCO (2018). Education for sustainable development (ESD) beyond 2019. 204 EX/28, Paris.

[2] S. Sterling, "Chapter 5 - Higher education, sustainability, and the role of systematic learning" in Higher Education and the Challenge of Sustainability: Problematics, Promise and practice (Peter Blaze Corcoran \& Arjen E.J. Wals Eds.), 49-70, Netherlands, 2004.

[3] A. Leicht, J. Heiss, and W. J. Byun in Issues and trends in Education for sustainable Development. Published by the United Nations Educational, Scientific and Cultural Organization, Paris, 2018.

[4] R. Lozano, M. Y. Merrill, K. Sammalisto, K. Ceulemans, and F. J. Lozano, "Connecting Competences and Pedagogical Approaches for 
Sustainable Development in Higher Education: A Literature Review and Framework Proposal," Sustainability, 9, 1889-1904, 2017.

[5] W. Lambrechts, I. Mulá, K. Ceulemans, I. Molderez, and V. Gaeremynnck, "The integration of competences for sustainable development in higher education: an analysis of bachelor programs in management," Journal of Cleaner Production, 48, 65-73, 2013.

[6] D. Cotton and J. Winter, "It's not just bits of paper and light bulbs: A review of sustainability pedagogies and their potential for use in higher education" in Sustainability Education: Perspectives and Practice across Higher Education (Jones, P., Selby, D., Sterling, S., Eds.), Earthscan: London, UK; New York, NY, USA, 2010.

[7] M. Murga-Menoyo, "Learning for Sustainable Economy: Teaching of Green Competencies in the University," Sustainability 6, 2974-2992, 2014.

[8] J. Segalás, D. Ferrer-Balas, and K. F. Mulder, "What do engineering students learn in sustainability courses? The effect of the pedagogical approach," Journal of Cleaner Production, 18, 275-284, 2010.

[9] E. R. Kahu, C. Stephens, L. Leach, and N. Zepke, "The engagement of mature distance students," Journal Higher Education Research \& Development, 32(5), 791-804, 2013.

[10] W. A. Astin, "Student Involvement: A Developmental Theory for Higher Education," Journal of College Student Development, 40(5), 518-529, 1999.

[11] J. B. Biggs and K. F. Collis, Evaluating the quality of learning: The SOLO taxonomy (Structure of the Observed Learning Outcome) pp. 23-29. In Academic Press Inc. New York, 1982.
[12] H. S. Barrows, "A taxonomy of problemsbased learning methods," Medical Education, 20(6), 481-486, 1986.

[13] M. Garmendia, J. I. Barragués, K. Zuza, and J. Guisasola, "Faculty development project for Science, Mathematics and Technology teachers on Problem and Project Based Learning methodologies," Enseñanza de las Ciencias, 32(2), 113-129, 2014.

[14] J. A. Llorens-Molina, "El aprendizaje basado en problemas como estrategia para el cambio metodológico en los trabajos de laboratorio," Quimica Nova, 994-999, 2010.

[15] B. Marlies, F. Dochy, and K. Struyven, "The effects of different learning environments on students' motivation for learning and their achievement," British Journal of Educational Psychology, 484-501, 2013.

[16] S. M. M. Loyens, S. H. Jones, J. Mikkers, and T. van Gog, "Problem-based learning as a facilitator of conceptual change," Learning and Instruction, 38, 34-42, 2015.

[17] Yepez-Salmon, "Construction d'un outil d'évaluation environnementale des écoquartiers: vers une méthode systémique de mise en oeuvre de la ville durable," Universitè Bordeaux, 2011.

[18] M. Lotteau, G. Yepez-Salmon, and N. Salmon, "Environmental assessment of sustainable neighborhood projects through NEST, a decision support tool for early stage urban planning," Procedia Engineering, 115, 6976, 2015.

[19] F. Zamora-Polo and J. Sánchez-Martín, "Teaching for a better world. Sustainability and sustainable development goals in the construction of a change-maker university," Sustainablity, 11(15), 4224, 2019. 
[20] P. P. Heppner and C. E. Baker, "Assessment in action. Applications of the problem solving inventory," Measurement and Evaluation in Counseling and Development 29, 229-241, 1997.

[21] J. Ortega y Gasset, "Misión de la Universidad", 1930 